\begin{tabular}{c} 
JURNAI R RS'II \\
IAll $\begin{array}{c}\text { (Rekayasa Sistem dan Teknologi Informasi) } \\
\text { Vol.4No.6(2020) } 1110-1116\end{array}$ \\
\hline
\end{tabular}

\title{
Pengambilan Keputusan Multi Hesitant N-Soft Sets
}

\author{
Fatia Fatimah \\ Jurusan Matematika, Fakultas Sains dan Teknologi, Universitas Terbuka \\ fatia@ecampus.ut.ac.id
}

\begin{abstract}
In everyday life, we generally have difficulty in making decision when we face with multi-criteria and many different opinions from friends or experts. So that, a representative model is needed to handle such cases. In this article, we introduce a new hybrid model of $N$-soft sets called multi hesitant $N$-soft sets (MHNSS). The multi hesitant $N$-soft sets is the extension of $N$-soft sets theory which is needed for multicriteria from some group decision makers. We propose the decision making algorithm of MHNSS dan apply it with real life data of distance education especially online learning using webinar tutorial. The population are tutors of Universitas Terbuka Padang that using webinar tutorial between April until May 2020. We use random sampling and spread the questionnaires online to collect data. As a result, by using the MHNSS algorithm, we conclude that webinar tutorial is effective for conceptual subjects.

Keywords: decision making, soft sets, $N$-soft sets, hesitant $N$-soft sets, webinar tutorial.
\end{abstract}

\begin{abstract}
Abstrak
Dalam kehidupan sehari-hari kita sering menemui kesulitan dalam mengambil keputusan jika berhadapan dengan multi kriteria dan banyaknya ragam pendapat teman atau ahli. Akibatnya, dibutuhkan model yang representatif untuk menangangi kasus seperti itu. Pada artikel ini, kami mengusulkan kombinasi baru dari $N$-soft sets yang dinamai Multi Hesitant $N$-Soft Sets (MHNSS). Konsep MHNSS merupakan bentuk perluasan $N$-soft sets yang diperlukan untuk merepresentasikan multi pendapat dari ragam responden untuk multi kriteria serta multi keputusan. Artikel ini juga memperkenalkan prosedur pengambilan keputusan menggunakan MHNSS dan menerapkannya pada data real bidang pendidikan jarak jauh khususnya pelaksanaan pembelajaran secara daring menggunakan tutorial webinar (tuweb). Populasi penelitian ini adalah tutor Universitas Terbuka Padang yang mengikuti tuweb pada April sampai Mei 2020. Sampel diambil secara acak dengan instrumen penelitian berupa kuesioner yang disebarkan secara daring. Berdasarkan olahan data dengan menggunakan algoritma MHNSS diperoleh hasil bahwa tutorial webinar lebih sesuai untuk jenis mata kuliah konseptual atau teori.
\end{abstract}

Kata kunci: pengambilan keputusan, soft sets, $N$-soft sets, hesitant $N$-soft sets, tutorial webinar

\section{Pendahuluan}

Pengambilan keputusan diperlukan dalam setiap sisi kehidupan baik untuk hal sederhana dalam kehidupan sehari-hari seperti memutuskan untuk membeli produk, Hal yang menarik tentang soft sets adalah ciri khas dari memilih menu makanan, menentukan rute wisata sampai teori ini yang fleksibel terhadap atribut sehingga dapat ke hal yang kompleks seperti keputusan medis saat memenuhi ragam tipe pengambil keputusan. Teori soft mendiagnosa penyakit pasien, keputusan untuk sets diperkenalkan oleh Molodtsov [3] pertama kali pada memperluas cabang perusahaan, kinerja pemasaran [1], tahun 1999. Pada perkembangannya, peneliti terus serta sistem pendidikan yang efektif sesuai kebutuhan memperluas teori ini. Penelitian soft sets untuk dan kondisi terkini. Secara umum, keputusan dapat pengambilan keputusan secara garis besar dapat disederhanakan menjadi setuju, tidak setuju atau netral. dikelompokkan menjadi tiga bagian. Pertama, penilaian Namun faktanya ketika mengambil keputusan banyak biner yang dapat dicek pada artikel [4], [5], dan [6]. hal yang harus dipertimbangkan serta ragam pendapat Kedua, penilaian non-biner berbentuk interval tertutup yang bersumber dari berbagai sumber atau orang.

Teori-teori matematika terus dikembangkan untuk menjembatani permasalahan pengambilan keputusan khususnya pada kasus ketidakpastian atau ketidaktentuan diantaranya rough sets [2] dan soft sets [3]. interval-valued hesitant fuzzy soft sets [9], intervalvalued fuzzy soft sets [10] dan expanded dual hesitant Diterima Redaksi : 24-11-2020 | Selesai Revisi : 07-12-2020| Diterbitkan Online : 20-12-2020 
fuzzy sets [11]. Ketiga, penilaian non biner real. Populasi penelitian adalah tutor Universitas menggunakan $N$-array yang dikenal dengan istilah $N$ - Terbuka Padang yang mengikuti tuweb selama dua soft sets [12].

Perluasan soft sets berupa peringkat yang diperkenalkan pertama kali oleh Fatimah dkk. [12] dapat menangani pengambilan keputusan untuk ketiga tipe penilaian yang dibahas sebelumnya yaitu biner, non biner berupa interval tertutup dan non biner berupa $N$-array.

Penelitian terkait pengambilan keputusan menggunakan pendekatan $\mathrm{N}$-soft sets terus berkembang seperti pada [13], [14], dan [15] serta kombinasi $N$-soft sets dengan teori-teori menjadi perhatian peneliti diantaranya fuzzy $N$-soft sets [16], hesitant $N$-soft sets [17], [18], intervalvalued hesitant fuzzy $N$-soft sets [19], dan pendekatan $N$ soft set pada rough sets [20]. Namun penelitian $N$-soft sets yang dapat mewadahi pendapat multi responden dari ragam kelompok belum pernah dibahas sehingga perlu ada solusi.

Oleh karena itu, penelitian ini bertujuan untuk membuat algoritma pengambilan keputusan multi $N$-soft sets dengan skema multi hesitant. Secara sederhana, road map penelitian ini disajikan pada Gambar 1.

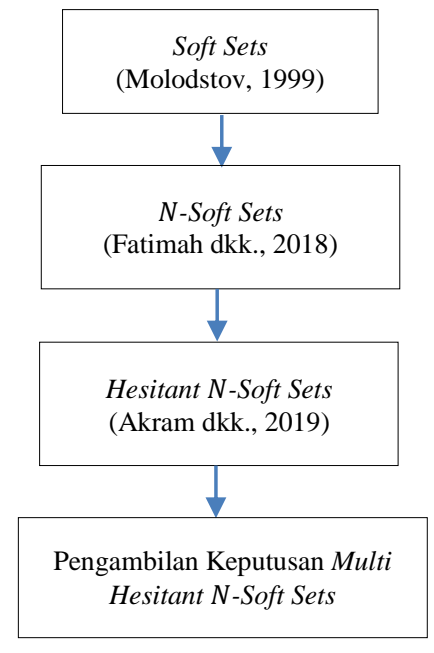

Gambar 1. Road Map Penelitian

\section{Metode Penelitian}

Penelitian ini menggunajan kajian teoritis dan praktis. Kajian teroritis diperlukan karena akan mendefinisikan bentuk dari multi $N$-soft sets dan multi hesitant $N$-soft sets sehingga perlu membahas definisi yang mendasarinya yaitu soft sets, dan $N$-soft sets serta hesitant $N$-soft sets. Tahap berikutnya, dibuat algoritma pengambilan keputusan multi hesitant $N$-soft sets. Pada kajian praktis, temuan algoritma yang dibuat diterapkan pada data real dalam hal ini adalah data primer yaitu tentang efektifitas pembelajaran menggunakan tutorial webinar. Untuk lebih jelas, tahapan penelitian dapat dilihat pada Gambar 2.

Setelah algoritma pengambilan keputusan MHNSS

selesai dibuat, dilanjutkan dengan penerapan pada data Bentuk tabular dari $N$-soft set disajikan pada Tabel 1.
Studi Literatur

Soft Sets, N-Soft Sets, Hesitant N-Soft Sets

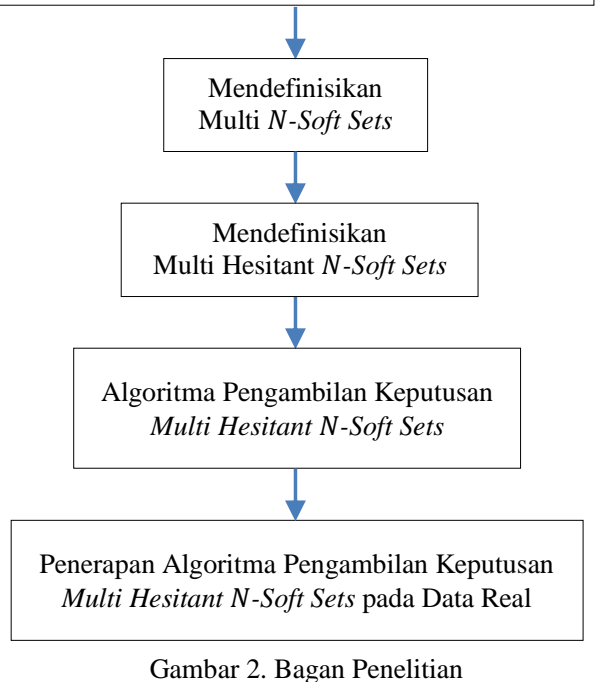

Selanjutnya, artikel ini menggunakan notasi sebagai berikut. Himpunan semesta objek dinyatakan dengan notasi $U$, himpunan semesta paramater atau atribut disimbolkan dengan $E$ dengan $A \subseteq E$ dan himpunan peringkat terurut menggunakan notasi $R=\{0,1, \ldots, N-$ 1) dimana $N=\{2,3, \ldots\}$.

Pada bagian ini, definisi teori-teori terkait disajikan. Definisi soft sets dapat dilihat pada Definisi 1 berikut.

Definisi 1. [3]. Soft sets atas semesta $U$ dinotasikan dengan $(F, A)$ merupakan pemetaan yang didefinisikan dengan rumus 1 berikut:

$F: A \rightarrow 2^{U}$

Penelitian tentang soft sets dan perluasannya terus berkembang pesat hingga kini. Beberapa diantaranya dapat dilihat pada [4]-[12].

Fatimah dkk. [12] mengusulkan $N$-soft set sebagai konsep baru yang belum pernah dibahas sebelumnya. Untuk lebih jelasnya, berikut ditampilkan definisi dari $N$-soft set (Definisi 2).

Definisi 2. [12] $N$-Soft Set (NSS) atas $U$ dinotasikan dengan $(F, A, N)$ didefinisikan sebagai pemetaan (rumus 2) berikut:

$F: A \rightarrow 2^{U \times R}$

untuk setiap $a \in A$ terdapat secara tunggal pasangan terurut $\left(u, r_{a}\right) \in U \times R$ sedemikian sehingga $\left(u, r_{a}\right) \in$ $F(a) \in U, r_{a} \in R$. 
Tabel 1. $N$-Soft Set $(F, A, N)$

\begin{tabular}{ccccc}
\hline$(F, A, N)$ & $a_{1}$ & $a_{2}$ & $\cdots$ & $a_{q}$ \\
\hline$u_{1}$ & $\left\{r_{11}\right\}$ & $\left\{r_{12}\right\}$ & $\ldots$ & $\left\{r_{1 q}\right\}$ \\
$u_{2}$ & $\left\{r_{21}\right\}$ & $\left\{r_{22}\right\}$ & $\ldots$ & $\left\{r_{2 q}\right\}$ \\
$\ldots$ & $\ldots$ & $\ldots$ & $\ldots$ & $\ldots$ \\
$u_{p}$ & $\left\{r_{p 1}\right\}$ & $\left\{r_{p 2}\right\}$ & $\ldots$ & $\left\{r_{p q}\right\}$ \\
\hline
\end{tabular}

Selanjutnya, $N$-Soft Set dikombinasikan dengan teoriteori uncertainty lainnya. Salah satu dari penelitian tersebut menghasilkan model yang dikenal dengan istilah Hesitant $N$-Soft Set. Definisinya dapat dilihat pada Definisi 3.

Definisi 3. [17] Hesitant $N$-Soft Set (HNSS) atas $U$ ditulis dengan notasi $(H, A, N)$ didefinisikan sebagai sebuah pemetaan seperti disajikan pada rumus 3 berikut:

$$
H: A \rightarrow 2^{U \times R}
$$

dengan syarat untuk setiap $a \in A$ dan $u \in U$ terdapat paling sedikit satu pasangan terurut $\left(u, r_{a}\right) \in U \times R$ sedemikian sehingga $\left(u, r_{a}\right) \in H(a) \in U, r_{a} \in R$.

Untuk kebutuhan pengambilan keputusan dengan multi responden perlu didefinisikan multi $N$-Soft Set sebagai berikut.

Definisi 4. Multi $N$-Soft Set (MNSS) atas $U$ merupakan bentuk $N$-Soft Set yang melibatkan responden lebih dari satu yaitu $O=\left\{o_{k}\right\}$ dimana $k \geq 2$.

Selanjutnya, kami mendefinisikan multi hesitant $N$-Soft Set untuk merepresentasikan pengambilan keputusan 8 . dengan multi responden dengan tetap mempertimbangkan jumlah penilaian dari masingmasing individu. Detil definisi disajikan pada Definisi 5 berikut.

Definisi 5. Misalkan $O=\left\{o_{k}\right\}$ himpunan responden. Multi Hesitant $N$-Soft Set (MHNSS) atas $U,(\widehat{H}, A, N)$, adalah pemetaan seperti pada rumus 4 :

$\widehat{H}: A \rightarrow 2^{U \times R_{O}}$

untuk setiap $a \in A$ dan $u \in U$ terdapat paling sedikit satu pasangan terurut yang memiliki frekuensi peringkat ditulis $\left(u, r_{a}\left(t_{a}\right)\right) \in U \times R_{O}$ dimana $t_{a}$ merupakan frekuensi peringkat $r_{a}$ dengan $\sum t_{a}=\sum o_{k}$.

Multi hesitant $N$-soft set disajikan juga dalam bentuk tabular seperti dapat dilihat pada Tabel 2.

Tabel 2. Multi Hesitant $N$-Soft Set $(\widehat{H}, A, N)$

\begin{tabular}{cccc}
\hline & $a_{1}$ & $\cdots$ & $a_{q}$ \\
\hline$u_{1}$ & $\left\{r_{1}^{\left\langle u_{1}, a_{1}\right\rangle}\left(t_{1}\right), \ldots, r_{N}^{\left\langle u_{1}, a_{1}\right\rangle}\left(t_{N}\right)\right.$ & $\cdots$ & $\left\{r_{1}^{\left\langle u_{1}, a_{q}\right\rangle}\left(t_{1}\right), \ldots, r_{N}^{\left\langle u_{1}, a_{q}\right\rangle}\left(t_{N}\right)\right.$ \\
$u_{2}$ & $\left\{r_{1}^{\left\langle u_{2}, a_{1}\right\rangle}\left(t_{1}\right), \ldots, r_{N}^{\left\langle u_{2}, a_{1}\right\rangle}\left(t_{N}\right)\right.$ & $\cdots$ & $\left\{r_{1}^{\left\langle u_{2}, a_{q}\right\rangle}\left(t_{1}\right), \ldots, r_{N}^{\left\langle u_{2}, a_{q}\right\rangle}\left(t_{N}\right)\right.$ \\
$\ldots$ & $\ldots$ & $\ldots$ & $\ldots$ \\
$u_{p}$ & $\left\{r_{1}^{\left\langle u_{p}, a_{1}\right\rangle}\left(t_{1}\right), \ldots, r_{N}^{\left\langle u_{p}, a_{1}\right\rangle}\left(t_{N}\right)\right.$ & $\cdots$ & $\left\{r_{1}^{\left\langle u_{p}, a_{q}\right\rangle}\left(t_{1}\right), \ldots, r_{N}^{\left\langle u_{p}, a_{q}\right\rangle}\left(t_{N}\right)\right.$ \\
\hline
\end{tabular}

Terkait pengambilan keputusan MHNSS perlu dibuat algoritma yang representatif sesuai definisi yang dibuat.
Algoritma pengambilan keputusan MHNSS menggunkan prinsip choice value. Algoritma 1 menyajikan setiap tahapan pengambilan keputusan yang diberi nama choice value MHNSS.

\section{Algoritma 1. Algoritma Choice Value MHNSS.}

1. Misalkan $U=\left\{u_{i}\right\}$ himpunan objek, $A=$ $\left\{a_{j}\right\}$ himpunan parameter, $O=\left\{o_{k}\right\}$ himpunan responden, $G=\left\{g_{l}\right\}$ himpunan kelompok responden dan $R=\{0,1, \ldots, N-1\}$ merupakan peringkat dengan $N=\{2,3, \ldots\}$. Input multi $N$-soft set $(F, A, N)$ sedemikian sehingga $\forall u_{i} \in U, a_{j} \in$ $A, \exists ! r_{i j} \in R$ untuk setiap $o_{k}$ dan $g_{l}$.

2. Untuk kelompok responden $g_{1}$, Tentukan MHNSS $(\widehat{H}, A, N)$

3. Hitung setiap skor geometrik MHNSS, $s_{g}\left(\hbar_{i j}\right)$, dengan $m$ banyaknya kombinasi $r_{i}^{\left\langle u_{1}, a_{1}\right\rangle} \times t_{i}$

$$
=\sqrt[m]{\left(r_{1}^{\left\langle u_{1}, a_{1}\right\rangle} \times t_{1}\right)+\cdots+\left(r_{N}^{\left\langle u_{1}, a_{1}\right\rangle} \times t_{N}\right)}
$$

4. Hitung Choice Value dari Skor Geometrik MHNSS $\delta_{i}=\sum_{j=1}^{q} s_{g}\left(\hbar_{i j}\right), \forall u_{i} \in U$.

5. Hitung threshold keputusan untuk kelompok $g_{1}$ dengan cara $T_{1}=p \sqrt{\left((N-1) \times t_{1}\right)+\left(N \times t_{N}\right)}$

Tentukan keputusan dari kelompok responden $1, \lambda_{g_{1}}=\operatorname{maks}_{i}$

7. Kembali ke langkah 2 sampai diperoleh keputusan untuk kelompok $g_{l}$ yaitu $\lambda_{g_{l}}=\operatorname{maks}_{i}$.

Keputusan hasil kesepakatan bersama diperoleh jika $\lambda=\lambda_{g_{1}} \cap \lambda_{g_{2}} \cap \ldots \cap \lambda_{g_{l}} \neq \emptyset$.

Bentuk flowchart dari algoritma 1 dapat dilihat pada Gambar 3. Algoritma tersebut diimplementasikan pada data real.

\section{Hasil dan Pembahasan}

Pada bagian ini, kami menerapkan algoritma Choice Value MHNSS untuk pengambilan keputusan pada data real pembelajaran daring menggunakan modus tutorial webinar. Data tersebut diuraikan pada Contoh 1.

Contoh 1. Misalkan $\boldsymbol{U}=\left\{\boldsymbol{u}_{\boldsymbol{i}}\right\}, \boldsymbol{i}=\mathbf{1}, \mathbf{2}, \mathbf{3}$ jenis mata kuliah yang dilaksanakan menggunakan tuweb yaitu $\boldsymbol{u}_{\mathbf{1}}$ merupakan mata kuliah berupa konseptual/teori, $\boldsymbol{u}_{\mathbf{2}}$ merupakan mata kuliah prosedural, dan $\boldsymbol{u}_{3}$ merupakan mata kuliah praktek/praktikum. Misalkan $\boldsymbol{A} \subseteq \boldsymbol{E}$ adalah himpunan parameter untuk mengukur efektifitas jenis mata kuliah yang sesuai untuk tutorial webinar dengan rincian:

\footnotetext{
$\boldsymbol{a}_{\mathbf{1}}$ menyatakan efektifitas penyampaian materi,

$\boldsymbol{a}_{2}$ menyatakan kemudahan penggunaan media,

$\boldsymbol{a}_{3}$ menyatakan ketercapaian kompetensi.
}

Paremeter tersebut dievaluasi dengan memberikan peringkat sebagai berikut:

0 berarti sangat tidak baik,

1 berarti tidak baik, 
2 berarti baik, dan

3 berarti sangat baik.

Responden $\boldsymbol{O}=\left\{\boldsymbol{o}_{\boldsymbol{i}}\right\}, \boldsymbol{i}=\mathbf{1}, \mathbf{2}, \ldots, \mathbf{1 4}$ merupakan tutor tutorial webinar dengan melihat persepsi berdasarkan gender yaitu laki-laki dan perempuan. Terdapat 14 orang untuk masing-masingnya sehingga total data adalah 28 orang.

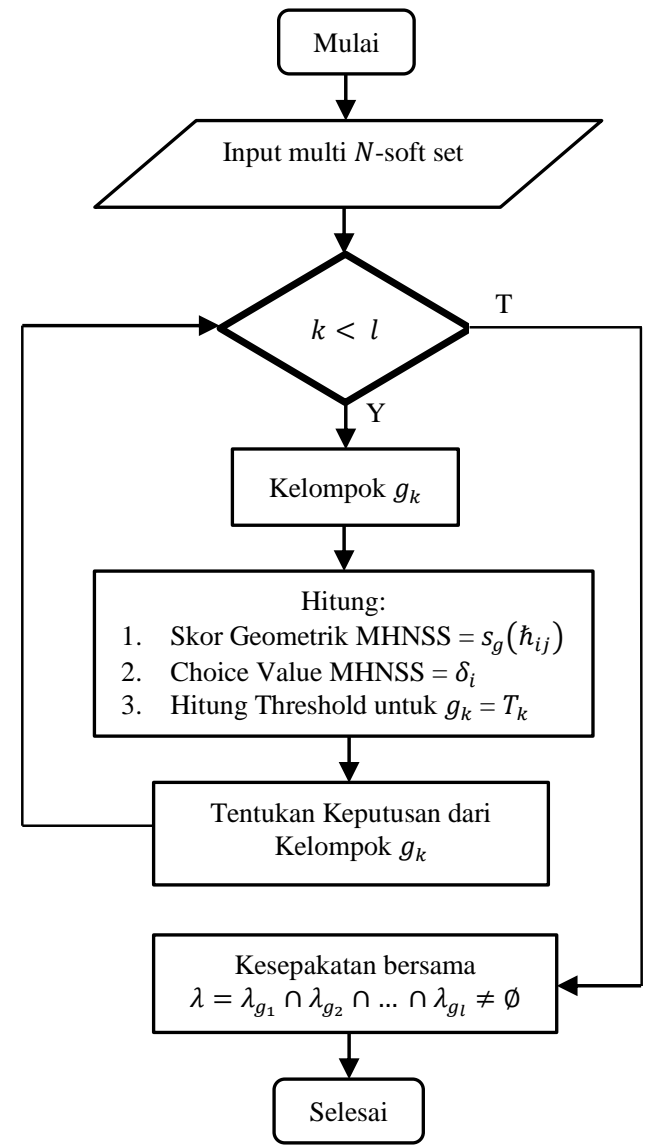

Gambar 3. Flowchart Algoritma 1 (Choice Value MHNSS)

Contoh 1 di atas diselesaikan menggunakan flowchart Algoritma 1. Rincian setiap tahapan dijelaskan sebagai berikut.

\section{A. Grup Pertama}

Untuk responden laki-laki selanjutnya disebut sebagai grup pertama dilakukan perhitungan pengambilan keputusan sesuai Algoritma 1.

\section{Input Multi $N$-Soft Set}

Hasil kuesioner disajikan dalam bentuk tabel Multi 4Soft Set (Tabel 3).

Tabel 3. Multi 4-Soft Set Tutor Laki-Laki

\begin{tabular}{ccccc}
\hline $\begin{array}{c}\text { Tutor } \\
\text { Laki-Laki }\end{array}$ & $\left(u_{i}, a_{j}\right)$ & $a_{1}$ & $a_{2}$ & $a_{3}$ \\
\hline \multirow{3}{*}{$o_{1}$} & $u_{1}$ & 3 & 2 & 3 \\
& $u_{2}$ & 3 & 2 & 2 \\
$o_{2}$ & $u_{3}$ & 3 & 1 & 2 \\
\hline
\end{tabular}

\begin{tabular}{|c|c|c|c|c|}
\hline & $u_{2}$ & 2 & 2 & 3 \\
\hline & $u_{3}$ & 2 & 3 & 3 \\
\hline \multirow[t]{3}{*}{$o_{3}$} & $u_{1}$ & 3 & 2 & 3 \\
\hline & $u_{2}$ & 3 & 2 & 3 \\
\hline & $u_{3}$ & 2 & 2 & 2 \\
\hline \multirow[t]{3}{*}{$O_{4}$} & $u_{1}$ & 2 & 3 & 3 \\
\hline & $u_{2}$ & 2 & 3 & 2 \\
\hline & $u_{3}$ & 2 & 3 & 3 \\
\hline \multirow[t]{3}{*}{$O_{5}$} & $u_{1}$ & 3 & 3 & 2 \\
\hline & $u_{2}$ & 3 & 3 & 2 \\
\hline & $u_{3}$ & 3 & 3 & 2 \\
\hline \multirow[t]{3}{*}{$o_{6}$} & $u_{1}$ & 2 & 2 & 2 \\
\hline & $u_{2}$ & 2 & 2 & 2 \\
\hline & $u_{3}$ & 3 & 2 & 2 \\
\hline \multirow[t]{3}{*}{$o_{7}$} & $u_{1}$ & 3 & 3 & 2 \\
\hline & $u_{2}$ & 2 & 3 & 2 \\
\hline & $u_{3}$ & 2 & 2 & 1 \\
\hline \multirow[t]{3}{*}{$o_{8}$} & $u_{1}$ & 2 & 2 & 2 \\
\hline & $u_{2}$ & 2 & 3 & 3 \\
\hline & $u_{3}$ & 2 & 2 & 2 \\
\hline \multirow[t]{3}{*}{$o_{9}$} & $u_{1}$ & 3 & 2 & 3 \\
\hline & $u_{2}$ & 3 & 2 & 3 \\
\hline & $u_{3}$ & 2 & 1 & 2 \\
\hline \multirow[t]{3}{*}{$o_{10}$} & $u_{1}$ & 2 & 3 & 2 \\
\hline & $u_{2}$ & 2 & 2 & 3 \\
\hline & $u_{3}$ & 1 & 2 & 3 \\
\hline \multirow[t]{3}{*}{$o_{11}$} & $u_{1}$ & 3 & 3 & 2 \\
\hline & $u_{2}$ & 3 & 2 & 3 \\
\hline & $u_{3}$ & 2 & 1 & 3 \\
\hline \multirow[t]{3}{*}{$o_{12}$} & $u_{1}$ & 3 & 3 & 2 \\
\hline & $u_{2}$ & 3 & 3 & 3 \\
\hline & $u_{3}$ & 3 & 2 & 3 \\
\hline \multirow[t]{3}{*}{$o_{13}$} & $u_{1}$ & 2 & 3 & 3 \\
\hline & $u_{2}$ & 2 & 3 & 3 \\
\hline & $u_{3}$ & 3 & 3 & 3 \\
\hline \multirow[t]{3}{*}{$o_{14}$} & $u_{1}$ & 3 & 2 & 3 \\
\hline & $u_{2}$ & 2 & 2 & 3 \\
\hline & $u_{3}$ & 2 & 2 & 3 \\
\hline
\end{tabular}

Pada Tabel 3 diketahui bahwa responden pertama memberikan penilaian untuk mata kuliah konseptual sebagai berikut yaitu angka 3 untuk efektifitas penyampaian materi dan ketercapaian kompetensi serta angka 2 untuk kemudahan penggunaan media. Dan seterusnya untuk dua jenis mata kuliah lainnya. Cara interpretasi yang sama untuk 13 responden lainnya.

\section{Hitung Multi HNSS.}

Selanjutnya hitung setiap frekuensi yang muncul untuk setiap peringkat yang diberikan untuk menilai masingmasing objek berdasarkan setiap parameter. Berdasarkan Tabel 3 dapat dihitung bahwa pada mata kuliah konseptual dari segi efektifitas penyampaian materi sebanyak enam responden laki-laki memberikan nilai 2 dan sebanyak delapan orang memberikan angka 3. Sementara untuk kemudahan penggunaan media dan ketercapaian kompetensi masing-masingnya mendapat tujuh responden memberi angka 2 dan sisanya memberikan angka 3 . 
Hal yang sama dilakukan untuk jenis mata kuliah lain. Sehingga rekap hasil perhitungan dapat disajikan dalam bentuk MHNSS seperti terlihat pada Tabel 4.

Tabel 4. Multi H4SS Tutor Laki-Laki

\begin{tabular}{cccc}
\hline$\left(u_{i}, a_{j}\right)$ & $a_{1}$ & $a_{2}$ & $a_{3}$ \\
\hline$u_{1}$ & $\{2(6), 3(8)\}$ & $\{2(7), 3(7)\}$ & $\{2(7), 3(7)\}$ \\
$u_{2}$ & $\{2(8), 3(6)\}$ & $\{2(8), 3(6)\}$ & $\{2(5), 3(9)\}$ \\
$u_{3}$ & $\{1(1), 2(8), 3(5)\}$ & $\{1(3), 2(7), 3(4)\}$ & $\{1(1), 2(6), 3(7)\}$ \\
\hline
\end{tabular}

3. Hitung Skor Geometrik Multi HNSS.

Skor geometrik multi H4SS grup pertama dihitung sebagai berikut:

- Untuk $\hbar_{11}=\{2(6), 3(8)\}$ maka

$s_{g}\left(\hbar_{11}\right)=\sqrt[2]{(2 \times 6)+(3 \times 8)=} 6$

- Untuk $\hbar_{12}=\hbar_{13}=\{2(7), 3(7)\}$ maka

$s_{g}\left(\hbar_{12}\right)=s_{g}\left(\hbar_{13}\right)=\sqrt[2]{(2 \times 7)+(3 \times 7)}=5,9$

- Untuk $\hbar_{21}=\hbar_{22}=\{2(8), 3(6)\}$ maka

$s_{g}\left(\hbar_{21}\right)=s_{g}\left(\hbar_{22}\right)=\sqrt[2]{(2 \times 8)+(3 \times 6)=} 5,8$

- Untuk $\hbar_{23}=\{2(5), 3(9)\}$ maka

$s_{g}\left(\hbar_{23}\right)=\sqrt[2]{(2 \times 5)+(3 \times 9)}=6,1$

- Untuk $\hbar_{31}=\{1(1), 2(8), 3(5)\}$ maka

$s_{g}\left(\hbar_{31}\right)=\sqrt[3]{(1 \times 1)+(2 \times 8)+(3 \times 5)=} 3,2$

- Untuk $\hbar_{32}=\{1(3), 2(7), 3(4)\}$ maka

$s_{g}\left(\hbar_{32}\right)=\sqrt[3]{(1 \times 3)+(2 \times 7)+(3 \times 4)=} 3,1$

- Untuk $\hbar_{33}=\{1(1), 2(6), 3(7)\}$ maka

$s_{g}\left(\hbar_{33}\right)=\sqrt[3]{(1 \times 1)+(2 \times 6)+(3 \times 7)}=3,2$

Hasil perhitungan skor geometrik disajikan dalam bentuk Tabel 5 .

\begin{tabular}{cccc}
\multicolumn{4}{l}{ Tabel 5. Skor Geometrik Tutor Laki-Laki } \\
\hline$\left(u_{i}, a_{j}\right)$ & $a_{1}$ & $a_{2}$ & $a_{3}$ \\
\hline$u_{1}$ & 6 & 5,9 & 5,9 \\
$u_{2}$ & 5,8 & 5,8 & 6,1 \\
$u_{3}$ & 3,2 & 3,1 & 3,2 \\
\hline
\end{tabular}

\section{Hitung Choice Value dari Skor Geometrik Multi HNSS.}

Perhitungan choice value dari skor geometric dengan menjumlahkan setiap skor yang diperoleh untuk setiap jenis mata kuliah. Hasil perhitungan ditampilkan pada Tabel 6.

Tabel 6. Choice Value Tutor Laki-Laki

\begin{tabular}{ccccc}
\hline$\left(u_{i}, a_{j}\right)$ & $a_{1}$ & $a_{2}$ & $a_{3}$ & $\begin{array}{c}\text { Choice } \\
\text { Value }\end{array}$ \\
\hline$u_{1}$ & 6 & 5,9 & 5,9 & 17,8 \\
$u_{2}$ & 5,8 & 5,8 & 6,1 & 17,7 \\
\hline
\end{tabular}

\begin{tabular}{lllll}
\hline$u_{3}$ & 3,2 & 3,1 & 3,2 & 9,5 \\
\hline
\end{tabular}

5. Hitung threshold keputusan grup pertama.

Threshold keputusan responden laki-laki dihitung sebagai berikut.

Threshold $=3 \sqrt[2]{2(7)+3(7)}=3 \times 5,9=17,7$.

6. Tentukan keputusan.

Berdasarkan nilai choice value pada Tabel 6 diketahui bahwa urutan untuk jenis mata kuliah yang sesuai dengan skema tuweb adalah $u_{1}>u_{2}>u_{3}$. Karena threshold untuk grup pertama (tutor laki-laki) adalah 17,7 maka dapat disimpulkan bahwa menurut persepsi tutor laki-laki tuweb lebih sesuai untuk mata kuliah konseptual/teori dan prosedural karena nilai keduanya dapat dikatakan berimbang.

\section{B. Grup Kedua}

Untuk grup kedua, responden diambil dari tutor perempuan. Dengan cara yang sama diterapkan tahapantahapan Algoritma 1.

\section{Input Multi $N$-Soft Set}

Hasil kuesioner dari grup kedua disajikan dalam bentuk tabel multi 4-soft set (Tabel 7).

\begin{tabular}{|c|c|c|c|c|}
\hline & $\left(u_{i}, a_{j}\right)$ & $a_{1}$ & $a_{2}$ & $a_{3}$ \\
\hline \multirow{3}{*}{$o_{1}$} & $u_{1}$ & 2 & 2 & 2 \\
\hline & $u_{2}$ & 2 & 2 & 2 \\
\hline & $u_{3}$ & 2 & 2 & 2 \\
\hline \multirow{3}{*}{$o_{2}$} & $u_{1}$ & 2 & 3 & 3 \\
\hline & $u_{2}$ & 2 & 2 & 3 \\
\hline & $u_{3}$ & 3 & 3 & 3 \\
\hline \multirow[t]{3}{*}{$o_{3}$} & $u_{1}$ & 3 & 2 & 3 \\
\hline & $u_{2}$ & 3 & 2 & 3 \\
\hline & $u_{3}$ & 3 & 2 & 3 \\
\hline \multirow[t]{3}{*}{$o_{4}$} & $u_{1}$ & 2 & 2 & 3 \\
\hline & $u_{2}$ & 2 & 3 & 3 \\
\hline & $u_{3}$ & 2 & 2 & 3 \\
\hline \multirow[t]{3}{*}{$o_{5}$} & $u_{1}$ & 3 & 3 & 3 \\
\hline & $u_{2}$ & 3 & 3 & 3 \\
\hline & $u_{3}$ & 3 & 2 & 3 \\
\hline \multirow[t]{3}{*}{$o_{6}$} & $u_{1}$ & 3 & 3 & 3 \\
\hline & $u_{2}$ & 3 & 3 & 1 \\
\hline & $u_{3}$ & 2 & 2 & 1 \\
\hline \multirow[t]{3}{*}{$o_{7}$} & $u_{1}$ & 2 & 2 & 2 \\
\hline & $u_{2}$ & 2 & 2 & 1 \\
\hline & $u_{3}$ & 2 & 2 & 1 \\
\hline \multirow[t]{3}{*}{$o_{8}$} & $u_{1}$ & 3 & 2 & 2 \\
\hline & $u_{2}$ & 3 & 2 & 2 \\
\hline & $u_{3}$ & 3 & 2 & 2 \\
\hline \multirow[t]{3}{*}{$o_{9}$} & $u_{1}$ & 2 & 3 & 3 \\
\hline & $u_{2}$ & 2 & 3 & 3 \\
\hline & $u_{3}$ & 2 & 2 & 3 \\
\hline \multirow[t]{3}{*}{$o_{10}$} & $u_{1}$ & 2 & 2 & 3 \\
\hline & $u_{2}$ & 2 & 2 & 2 \\
\hline & $u_{3}$ & 2 & 1 & 2 \\
\hline
\end{tabular}




\begin{tabular}{ccccc}
\hline$o_{11}$ & $u_{1}$ & 2 & 3 & 2 \\
& $u_{2}$ & 2 & 3 & 2 \\
& $u_{3}$ & 2 & 2 & 2 \\
$o_{12}$ & $u_{1}$ & 3 & 2 & 2 \\
& $u_{2}$ & 3 & 2 & 2 \\
& $u_{3}$ & 3 & 1 & 2 \\
$o_{13}$ & $u_{1}$ & 3 & 3 & 3 \\
& $u_{2}$ & 3 & 2 & 3 \\
& $u_{3}$ & 3 & 2 & 3 \\
$0_{14}$ & $u_{1}$ & 3 & 2 & 3 \\
& $u_{2}$ & 3 & 2 & 3 \\
& $u_{3}$ & 3 & 2 & 3 \\
\hline
\end{tabular}

\section{Hitung Multi HNSS.}

Hasil perhitungan Multi H4SS untuk grup kedua disajikan pada Tabel 8 .

Tabel 8.Multi H4SS Tutor Perempuan

\begin{tabular}{cccc}
\hline$\left(u_{i}, a_{j}\right)$ & $a_{1}$ & $a_{2}$ & $a_{3}$ \\
\hline$u_{1}$ & $\{2(7), 3(7)\}$ & $\{2(8), 3(6)\}$ & $\{2(5), 3(9)\}$ \\
$u_{2}$ & $\{2(7), 3(7)\}$ & $\{2(9), 3(5)\}$ & $\{1(2), 2(5), 3(7)\}$ \\
$u_{3}$ & $\{2(7), 3(7)\}$ & $\{1(2), 2(11), 3(1)\}$ & $\{1(2), 2(5), 3(7)\}$ \\
\hline
\end{tabular}

\section{Hitung Skor Geometrik Multi HNSS.}

Skor geometrik multi H4SS grup kedua dihitung sebagai berikut:

- Untuk $\hbar_{11}=\hbar_{21}=\hbar_{31}=\{2(7), 3(7)\}$ maka

$s_{g}\left(\hbar_{11}\right)=s_{g}\left(\hbar_{21}\right)=s_{g}\left(\hbar_{31}\right)$

$$
=\sqrt[2]{(2 \times 7)+(3 \times 7)}=5,9
$$

- Untuk $\hbar_{12}=\{2(8), 3(6)\}$ maka

$s_{g}\left(\hbar_{12}\right)=\sqrt[2]{(2 \times 8)+(3 \times 6)}=5,8$

- Untuk $\hbar_{13}=\{2(5), 3(9)\}$ maka

$s_{g}\left(\hbar_{21}\right)=s_{g}\left(\hbar_{22}\right)=\sqrt[2]{(2 \times 5)+(3 \times 9)}=6,1$

- Untuk $\hbar_{22}=\{2(9), 3(5)\}$ maka

$s_{g}\left(\hbar_{22}\right)=\sqrt[2]{(2 \times 9)+(3 \times 5)=} 5,7$

- Untuk $\hbar_{23}=\hbar_{33}=\{1(2), 2(5), 3(7)\}$ maka

$s_{g}\left(\hbar_{23}\right)=s_{g}\left(\hbar_{33}\right)$

$=\sqrt[3]{(1 \times 2)+(2 \times 5)+(3 \times 7)}=3,2$

- Untuk $\hbar_{32}=\{1(2), 2(11), 3(1)\}$ maka

$s_{g}\left(\hbar_{32}\right)=\sqrt[3]{(1 \times 2)+(2 \times 11)+(3 \times 1)=} 3$

Hasil perhitungan skor geometrik disajikan dalam bentuk Tabel 9 .

Tabel 9. Skor Geometrik Tutor Perempuan

\begin{tabular}{cccc}
\hline$\left(u_{i}, a_{j}\right)$ & $a_{1}$ & $a_{2}$ & $a_{3}$ \\
\hline$u_{1}$ & 5,9 & 5,8 & 6,1 \\
$u_{2}$ & 5,9 & 5,7 & 3,2 \\
$u_{3}$ & 5,9 & 3 & 3,2 \\
\hline
\end{tabular}

4. Hitung Choice Value dari Skor Geometrik Multi HNSS

Pada Tabel 10 dapat dilihat hasil perhitungan choice value tutor perempuan.

Tabel 10. Choice Value Tutor Perempuan

\begin{tabular}{ccccc}
\hline$\left(u_{i}, a_{j}\right)$ & $a_{1}$ & $a_{2}$ & $a_{3}$ & $\begin{array}{c}\text { Choice } \\
\text { Value }\end{array}$ \\
\hline$u_{1}$ & 5,9 & 5,8 & 6,1 & 17,8 \\
$u_{2}$ & 5,9 & 5,7 & 3,2 & 14,8 \\
$u_{3}$ & 5,9 & 3 & 3,2 & 12,1 \\
\hline
\end{tabular}

\section{Hitung threshold Keputusan}

Threshold keputusan tutor perempuan dihitung sebagai berikut.

Threshold $=3 \sqrt[2]{2(7)+3(7)}=3 \times 5,9=17,7$.

6. Tentukan keputusan.

Berdasarkan Tabel 10 diketahui bahwa urutan untuk jenis mata kuliah yang sesuai dengan skema tuweb menurut tutor perempuan adalah $u_{1}>u_{2}>u_{3}$.

\section{Kesepakatan bersama}

Karena semua grup responden sudah diselesaikan (pada Contoh 1 berarti hanya ada dua grup yaitu tutor laki-laki dan tutor perempuan) dengan threshold kedua grup sama yaitu 17,7 dicari kesepakatan bersama dengan melihat irisan dari hasil keputusan masing-masing grup. Hasilnya adalah $u_{1}$. Dengan kata lain tuweb hanya sesuai untuk mata kuliah yang berjenis konseptual/teori.

\section{Kesimpulan}

$N$-soft set memberikan solusi agar dapat merepresentasikan penilaian $N$-array pada teori soft sets. Pada artikel ini diperkenalkan tiga kebaruan yaitu istilah multi $N$-soft set, multi hesitant $N$-soft set dan mengusulkan algoritma pengambilan keputusan untuk multi hesitant $N$-soft set.

Algoritma diterapkan pada data real bidang pendidikan khususnya pelaksanaan pembelajaran daring menggunakan skema tutorial webinar. Berdasarkan algoritma choice value multi hesitant $N$-soft sets diperoleh kepastian bahwa tutorial webinar lebih sesuai untuk mata kuliah berjenis konseptual atau teori sehingga kurang tepat jika digunakan untuk mata kuliah bersifat prosedural dan praktek atau praktikum.

Untuk lanjutan penelitian ini, penulis akan melakukan kajian terkait kebaruan yang sudah diusulkan dengan kombinasi $\mathrm{N}$-rough soft sets. Hal menarik dan perlu untuk dicarikan solusi pada penelitian yang akan datang adalah penerapannya pada data besar.

\section{Ucapan Terimakasih}

Penulis menyampaikan terima kasih kepada Universitas Terbuka yang telah membantu pendanaan riset untuk 
artikel ini dalam bentuk pendaanan penelitian tahun 2020 .

\section{Daftar Rujukan}

[1] Andriyansah and Fatimah, F., 2020, Developing the concept of ecustomer relationship management model to improve marketing performance, The 4th International Conference on E-commerce, E-Business and E-Government, pp. 22-26.

[2] Pawlak, Z., 2005, Some remarks on conflict analysis, European Journal of Operational Research, 166(3), pp. 649-654.

[3] Molodtsov, D., 1999, Soft set theory-first results, Computers and Mathematics with Applications, 37 (4-5), pp. 19-31.

[4] Roy, A.R., and Maji, P.K., 2007, A fuzzy soft set theoretic approach to decision making problems, Journal of Computational and Applied Mathematics, 203(2), pp. 412-418.

[5] Ali, M.I., Feng, F., Liu, X., Min, W.K., and Shabir, M., 2009, On some new operations in soft set theory, Computers \& Mathematics with Applications, 57(9), pp. 1547-1553.

[6] Ali, M.I., Mahmood, T., Muti Ur Rehman, M, and Aslam, M.F., 2015, On lattice ordered soft sets, Applied Soft Computing, 36, pp. 499-505.

[7] Fatimah, F., Rosadi, D., Hakim, R.B.F., and Alcantud, J.C.R., 2017, Probabilistic soft sets and dual probabilistic soft sets in decision-making, Neural Computing and Applications, 31(S1), pp. 397-407.

[8] Fatimah, F., Rosadi, D., and Hakim, R.B.F., 2018, Probabilistic soft sets and dual probabilistic soft sets in decision making with positive and negative parameters, Journal of Physics: Conference Series, 983 (1), 012112

[9] Peng, X., and Yang, Y., 2015. Interval-valued Hesitant Fuzzy Soft Sets and their Application in Decision Making, Fundamenta Informaticae, 141(1), pp. 71-93.
[10]Peng, X., and Yang, Y., 2017, Algorithms for interval-valued fuzzy soft sets in stochastic multi-criteria decision making based on regret theory and prospect theory with combined weight, Applied Soft Computing, 54, pp. 415-430.

[11]Fatimah, F., and Alcantud, J. C. R., 2018, Expanded Dual Hesitant Fuzzy Sets, IEEE International Conference on Intelligent Systems (IS), pp. 102-108

12]Fatimah, F., Rosadi, D., Hakim, R.B.F., and Alcantud, J.C.R., 2017, N-soft sets and their decision making algorithms, Soft Computing, 22(12), pp. 3829-3842.

13] Fatimah, F., 2018, Pengambilan keputusan incomplete N-Soft Sets pada data untuk mengukur indikator sustainable development goals. Book Chapter: Seminar Nasional FMIPA Universitas Terbuka, pp. 209-228.

14]Fatimah, F., and Andriyansah, 2020, Analisis fasilitas pariwisata menggunakan prosedur pengambilan keputusan NSS. Jurnal Rekayasa Sistem dan Teknologi Informasi, 4(1), pp. 135-141.

15]Akram, M., et al., 2020, Parameter reductions in N-soft sets and their applications in decision-making. Expert Systems, pp. 1-15.

[16] Akram, M., Adeel, A., and Alcantud, J.C.R., 2018, Fuzzy N-soft sets: A novel model with applications, Journal of Intelligent \& Fuzzy Systems, 35(4), pp. 4757-4771.

17]Akram, M., Adeel, A., and Alcantud, J.C.R., 2019, Group decision-making methods based on hesitant N-soft sets, Expert Systems with Applications, 115, pp. 95-105.

18] Akram, M., Adeel, A., and Alcantud, J.C.R., 2019, Hesitant fuzzy $\mathrm{N}$-soft sets: A new model with applications in decision-making, Journal of Intelligent \& Fuzzy Systems, 36(6), pp. 6113-6127.

[19] Akram, M., and Adeel, A., 2018, TOPSIS Approach for MAGDM Based on Interval-Valued Hesitant Fuzzy N-Soft Environment, International Journal of Fuzzy Systems, 21(3), pp. 993-1009.

[20] Alcantud, J.C.R., Feng, F., and Yager, R.R., 2019, An N-Soft Set Approach to Rough Sets, IEEE Transactions on Fuzzy Systems, pp. 1-13. 